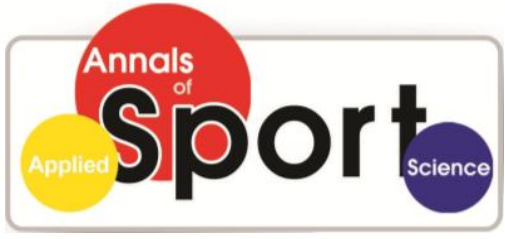

www.aassjournal.com

ISS N (Online): 2322 - 4479

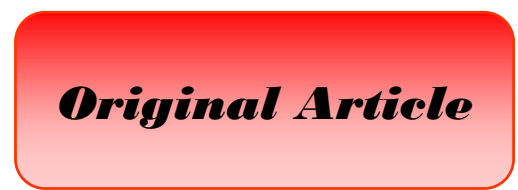

Received: $17 / 05 / 2014$

Accepted: 09/04/2015

\title{
Effects of Circuit Resistance Training with Crocus Sativus (Saffron) Supplementation on Plasma Viscosity and Fibrinogen
}

\section{${ }^{1}$ Abbass Ghanbari-Niaki', ${ }^{1}$ Ayoub Saeidi, ${ }^{1}$ Mahdi Aliakbari-Beydokhti, ${ }^{1}$ Sadegh Ardeshiri, ${ }^{1}$ Sarkawt Kolahdouzi, ${ }^{2}$ Mohammad Javad Chaichi, ${ }^{3}$ Bijan Hedayati-Monfared}

1. Faculty of Physical Education and Sport Sciences, University of Mazandaran, Babolsar, Iran.

2. Analytical Division, Faculty of Chemistry, University of Mazandaran, Babolsar, Iran.

3. Laboratory Sciences Division, Iran University of Medical Sciences, Tehran, Iran.

\section{BSTRACT}

A limited number of studies has been carried out concerning the combined effects of resistance training and saffron supplementation on cardiovascular risk factors. The aim of this study was to assess the effects of circuit resistance training with Crocus sativus (saffron) supplementation on plasma viscosity and fibrinogen. For this purpose, 44 healthy male subjects, based on individual characteristics and after homogenization, were divided into four groups, including water-training (WT; $n=11$ ), petal sweat-training (PST; $n=10$ ), bottom part of flower-training (BFT; $n=11$ ), and upper part of flower-training (UFT; $n=12$ ). Resistance training consisted of 12 stations (each station for 30 seconds with $40 \%$ of one repetition maximum) for 2 weeks ( 5 sessions per week). Saffron in the amount of $500 \mathrm{mg}$ was used twice daily, i.e. in the morning and immediately after exercise. Blood samples were taken before and 48 hours after the last exercise session and were analyzed for fibrinogen and plasma viscosity. Significant differences were observed between groups in plasma levels of fibrinogen $(\mathrm{P}=0.01)$. The post hoc test showed significant differences between the UFT and PST groups and the UFT and BFT groups (respectively, $\mathrm{P}=0.04$ and $\mathrm{P}=0.014$ ). In the post-test, plasma fibrinogen had significantly decreased in the WT $(\mathrm{P}=0.005)$, $\mathrm{PWT}(\mathrm{P}=0.003)$, and UFT $(\mathrm{P}=0.001)$ groups compared with pre-test data (within group difference). Moreover, plasma viscosity was significantly changed among groups $\left(\mathrm{F}_{3,37}=3.52, \mathrm{P}=0.024\right)$. The post hoc test showed significant differences between the UFT and WT groups $(\mathrm{P}=0.037)$. In post-test data, plasma viscosity had significantly decreased in the $\mathrm{WT}(\mathrm{P}=0.015)$ and UFT $(\mathrm{P}<0.001)$ groups compared with pre-test data. The present results show that circuit resistance training with saffron supplements can reduce cardiovascular risk factors (fibrinogen and plasma viscosity).

Key Words: Circuit resistance training, Saffron supplementation, Viscosity, Fibrinogen.

Corresponding Author:

Abbass Ghanbari-Niaki

E-mail: ghanbara@umz.ac.ir 


\section{INTRODUCTION}

Thrombus and atherosclerosis play important roles in cardiovascular and peripheral arterial system diseases and are of the most effective factors in mortality due to cardiovascular diseases in the industrialized world (1). Impairment of the rheological properties of normal blood is as an independent risk factor for coronary heart disease, especially viscosity which can increase coronary obstruction and blood pressure $(2,3)$. Increased blood viscosity may have adverse effects on blood flow and oxygen transport. Changes in levels of blood proteins, such as albumin and fibrinogen, increase according to the shape and size of the protein; the relationship between high levels of fibrinogen and increased blood and plasma viscosity is well understood. Fibrinogen is the largest plasma protein which includes an approximately $5.5 \%$ concentration of total plasma protein (4). Recent evidence has shown the role of fibrinogen in the pathogenesis of atherosclerosis vascular diseases and possibly as a risk factor for cardiovascular diseases (5). The role of fibrinogen is considered in blood homeostatic mechanisms and as a determinant of blood rheology through its influence on the red blood cell aggregation process (4). Increased plasma fibrinogen may cause adverse effects to the atherosclerosis process by increasing the interaction of platelets with the vessel wall, increasing blood viscosity through nonrheological routes such as blood coagulation, or by a direct effect on the vessel wall (6).

Blood viscosity generally depends on the blood concentration. In fact, hematocrit, viscosity, and blood viscosity are directly related to each other and inversely related to plasma volume (7). When hematocrit increases, blood viscosity increases; consequently, the blood flow rate decreases and thus, the supply of oxygen to tissue is reduced (7). The effects of different sports and physical activities on blood viscosity and fibrinogen levels were examined in the current study. The results demonstrated the relationship between maximal oxygen uptake and a higher level of physical fitness $(8,9)$. Conversely, some studies have reported no change, and some have reported an increase of $28 \%$ after resistance activity. Some other studies have reported an increase of $38 \%$ after aerobic activity (10). Long-term training is not usually associated with significant changes in hematocrit, but it is associated with an increase in total plasma protein, which is one of the mechanisms causing plasma viscosity to increase (9). Although it seems that plasma viscosity increases in response to long-term training, not getting an increase in hematocrit in response to such training may show slight changes in total viscosity (8). Despite assessing the effect of light circuit resistance exercises on hematorheologic parameters such as the volume of platelets, white blood cells, and red blood cells (11), there is little information about the effects of sports activities, especially resistance activities on blood viscosity, plasma, and fibrinogen. Moreover, the effect of resistance exercises, particularly short-term and sequential circuit with fooddrug supplementation has not yet been clarified. In one study using resistance exercises, however, it was shown that viscosity immediately increased and then decreased again during a 30 minute recovery period. Similar changes in levels of fibrinogen, plasma total protein, and albumin were seen, but at the end of the recovery period, these levels returned to the baseline (12). Considering the conflicting findings about blood viscosity, plasma, and fibrinogen as significant indices in cardiovascular diseases, the simultaneous use of a food-drug before or after physical exercise, especially sequential circuit resistance exercises, can undoubtedly provide a new area to manage the correct usage of food supplementation with training. Crocus sativus, or saffron, is 
one of the considerable plants for Iran and other nations and is known as an expensive but pleasant flavor for everyone. General characteristics of the plant include it containing $10 \%$ moisture, $12 \%$ protein, $5 \%$ fat, $5 \%$ minerals, $5 \%$ crude fiber, and $63 \%$ carbohydrates (starches, restored sugars, pentoses, riboflavin and thiamine) (13).

The effect of saffron tablets on the shortterm safety and tolerability of healthy adults was investigated. In this study, a dose of 200 mg of saffron reduced the platelet count, international normalized ratio (INR), and the time of bleeding $(14,15)$. The watery essence of saffron inhibited the platelet aggregation induced by ADP, epinephrine, and collagen. Chives of saffron have a protein which compresses the platelets (16). It is said that saffron has antioxidant properties that increase glutation levels and prevent lipid oxidation (17). Studies have reported the effects of saffron on atherosclerosis (18-20); it decreases lipid deposits in artery walls and consequently decreases atherosclerosis by reducing adhesive vascular molecules (20). Thus, considering the influence of resistance training on permanent increases in blood viscosity and plasma induced by increased fibrinogen, albumin, total protein, and hematocrit following resistance activities (21), this study sought to answer the questions of whether taking all parts of saffron confirm or reject the possible effects of saffron with short-term resistance training and whether supplementation with various parts of the saffron flower strengthens the anticoagulant effects of physical exercise, thereby having a protective effect. The present study was designed to examine the effects of circuit resistance training while simultaneously taking various parts of the saffron flower (upper part, bottom part, and petal sweat) on viscosity and fibrinogen.

\section{MATERIALS AND METHODS}

Participants. Forty-four students at Mazandaran University participated voluntarily in this study. Before participation, the whole methodology was explained to them, they completed a medical questionnaire, and they gave written consent. Inclusion criteria were no addiction to drugs, lack of regular physical activity for at least 6 months, no history of kidney, liver, cardiovascular diseases or diabetes or any injury or physical problem. Subjects were divided homogenously into 4 groups:

1) Water + training (WT: $n=11)$

2) Petal sweat + training (PST: $n=10)$

3) Bottom part of flower + training (BFT: $n=11)$

4) Upper part of flower + training (UFT: $n=12)$.

Table 1. Descriptive characteristics of group samples (Mean \pm SD)

\begin{tabular}{ccccc}
\hline Group & UFT & WT & PST & BFT \\
\hline $\begin{array}{c}\text { Age } \\
\text { years })\end{array}$ & $21.50 \pm 1.93$ & $21.91 \pm 2.34$ & $22.00 \pm 2.35$ & $21.18 \pm 1.72$ \\
\hline $\begin{array}{c}\text { Height } \\
(\mathrm{cm})\end{array}$ & $175.92 \pm 5.31$ & $178.18 \pm 4.75$ & $175.10 \pm 6.08$ & $175.36 \pm 4.6$ \\
\hline $\begin{array}{c}\text { Weight } \\
(\mathrm{kg})\end{array}$ & $67.42 \pm 8.46$ & $69.91 \pm 9.40$ & $73.10 \pm 10.51$ & $67.36 \pm 8.21$ \\
\hline $\begin{array}{c}\text { BMI } \\
\left(\mathrm{kg} / \mathrm{m}^{2}\right)\end{array}$ & $21.75 \pm 1.96$ & $22.00 \pm 2.96$ & $23.90 \pm 2.72$ & $21.82 \pm 2.60$ \\
\hline
\end{tabular}

UFT: Upper part of flower + training, WT: Water + training, PST: Petal sweat + training, BFT: Bottom part of flower + training

Procedure. Subjects received $500 \mathrm{mg}$ of saffron in two steps, a $250 \mathrm{mg}$ capsule after breakfast and then a $250 \mathrm{mg}$ capsule along with $100 \mathrm{ml}$ of water immediately after 
exercise. The PST group consumed $200 \mathrm{ml}$ of petal sweat with a placebo, and the WT group consumed $200 \mathrm{ml}$ of water with a placebo. According to the exercise procedure, subjects were familiarized with the working environment before performing circuit resistance exercises, and they came to the exercise location to determine $1 \mathrm{RM}$ of activities during three separate sessions. Values of 1RM of activities such as the squat, bench press, standing calf raise, military press, leg press, rowing, leg extension, leg curl, French press, trunk extension, and situps were calculated using the trial and error and the Berzisky equation methods (22).

$$
\begin{aligned}
& \text { Berzisky equation to calculate 1RM: } \\
& 1 \mathrm{RM}=\frac{(\mathrm{kg}) \text { displaced weight }}{1.0278}-(\text { number of repetitions up to fatigue } \times 0.0278)
\end{aligned}
$$

Subjects performed these activities with $40 \%$ of mean 1RM and moderate velocity for 2 weeks ( 5 sessions per week). Each exercise session consisted of 5 minutes of warm-up and then nonstop exercise between the 12 activity stations. The duration of each station was 30 seconds. The number of repetitions for each subject at each station was recorded. For the first two sessions, one period of exercise was done. From the third session on, subjects did exercises for two periods between which they took an active rest for 3 minutes. Blood was sampled from an arm vein after 10 to 12 hours fasting, two times: 48 hours before starting exercises and 48 hours after the latest session of exercises. Blood samples were poured into test tubes containing EDTA and centrifuged for 10 minutes at 3000 rounds per minute. Then, the separated plasma was used to analyze fibrinogen, and other factors were used to calculate viscosity. Fibrinogen was measured by a set (LABI TECH) made in Germany. Viscosity was calculated using the following formula (7):

Plasma viscosity $=1.352+0.0167 \times$ total cholesterol $(\mathrm{mmol})+0.0285 \times$ fibrinogen $(\mathrm{g} / \mathrm{l})+$ $0.0054 \times$ triglyceride $(\mathrm{mmol})+0.00318 \times$ hematocrit $-0.03-\mathrm{c}(\mathrm{mmol})$

Statistical Analysis. Data was analyzed using SPSS software version 20. Normal distribution of data was confirmed using the Kolmogorov Smirnov test. Repeated measures $(4 \times 2)$ ANOVA was also used to analyze data. Independent $\mathrm{t}-$ test was used to find intergroup changes. A level of (0.05) was considered significant.

\section{RESULTS}

Statistical analysis showed no significant differences between plasma levels of fibrinogen in the groups before and after exercise using the two-way repeated ANOVA test, $\left(f_{3,40}=0.206, p=0.89\right)$, but there was a significant difference between various times $\left(f_{1,40}=39.96, p<0.001\right)$. Results of the Bonferoni test showed no significant differences between groups before and after exercise $(\mathrm{P}>0.05)$. A negative interaction between time and group ( $f_{3}, 40=4.43, p=0.009$ ) was also observed (Fig. 1). Using the dependent $\mathrm{t}$ test, a significant difference was observed in preand post-test data in the WT $\left(\mathrm{t}_{10}=3.54, \mathrm{p}=\right.$ $0.005)$, PST ( $\mathrm{t}_{9}=3.06, \mathrm{p}=0.003$ ), and UFT $\left(\mathrm{t}_{11}=4.52, \mathrm{p}=0.001\right)$ groups, but no significant difference was seen between pretest and post-test data of the BFT group ( $\mathrm{t}_{10}$ $=1.52, \mathrm{p}=0.15)$ (Fig. 1). 
Statistical analysis of plasma viscosity levels in pre-test and post-test data using two way repeated ANOVA showed no significant differences between groups $\left(\mathrm{f}_{3}\right.$, $40=0.997, \mathrm{p}=0.4)$, but there was a significant difference between various times $\left(f_{1}, 40=24.42, p<0.001\right)$. Results of the Bonferoni test on pre- and post-test data showed no significant differences in times between the various groups $(\mathrm{P}>0.05)$. There was, however, a significant interaction between time and group $\left(\mathrm{f}_{3,40}=3.19, \mathrm{p}=\right.$ 0.034) (Fig. 1).

Using the dependent $\mathrm{t}$ test, significant differences between pre-test and post-est data in the WT group $\left(\mathrm{t}_{10}=2.93, \mathrm{p}=0.015\right)$ and the UFT group $\left(\mathrm{t}_{11}=5.42, \mathrm{p}<0.001\right)$ were observed (Fig. 2).

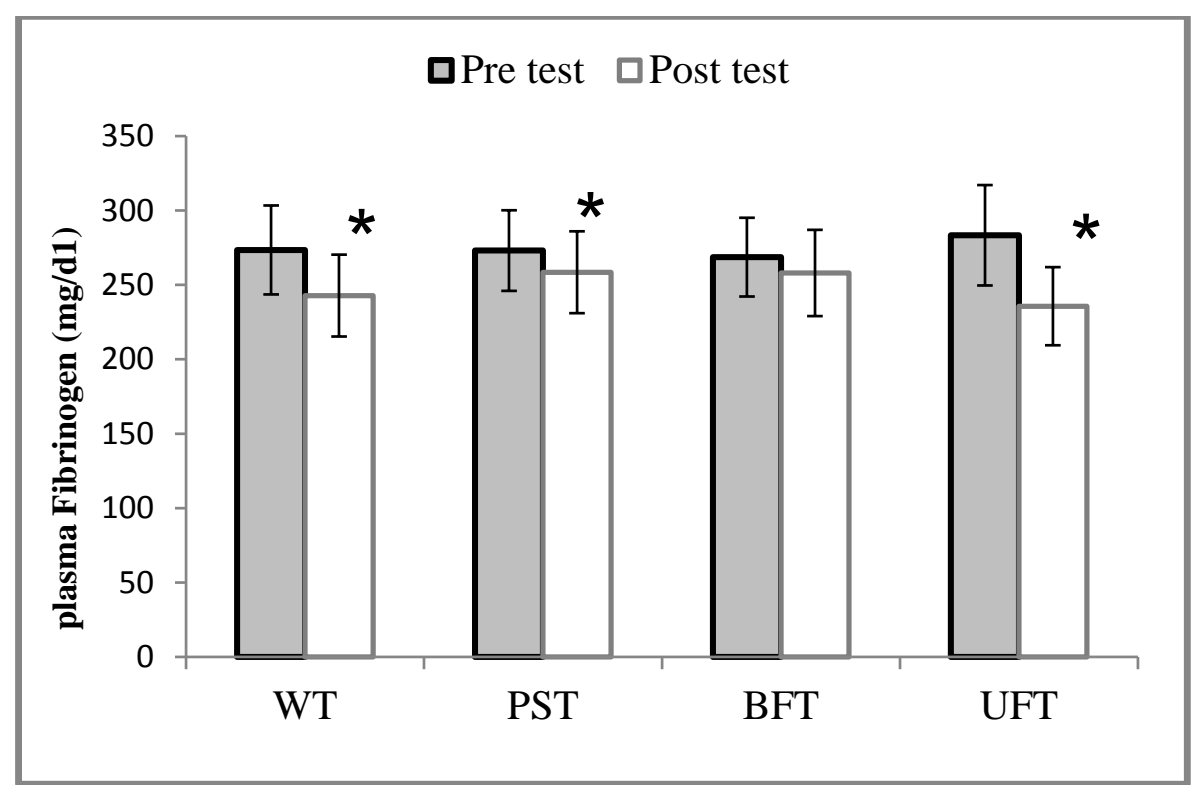

Fig 1. Fibrinogen data. *shows significant difference between pre-test and post-test data in the groups $(\mathrm{p}<0.05)$. WT, water-training; PST, petal sweat-training; BFT, bottom part of flower-training; UFT, upper part of flower-training.

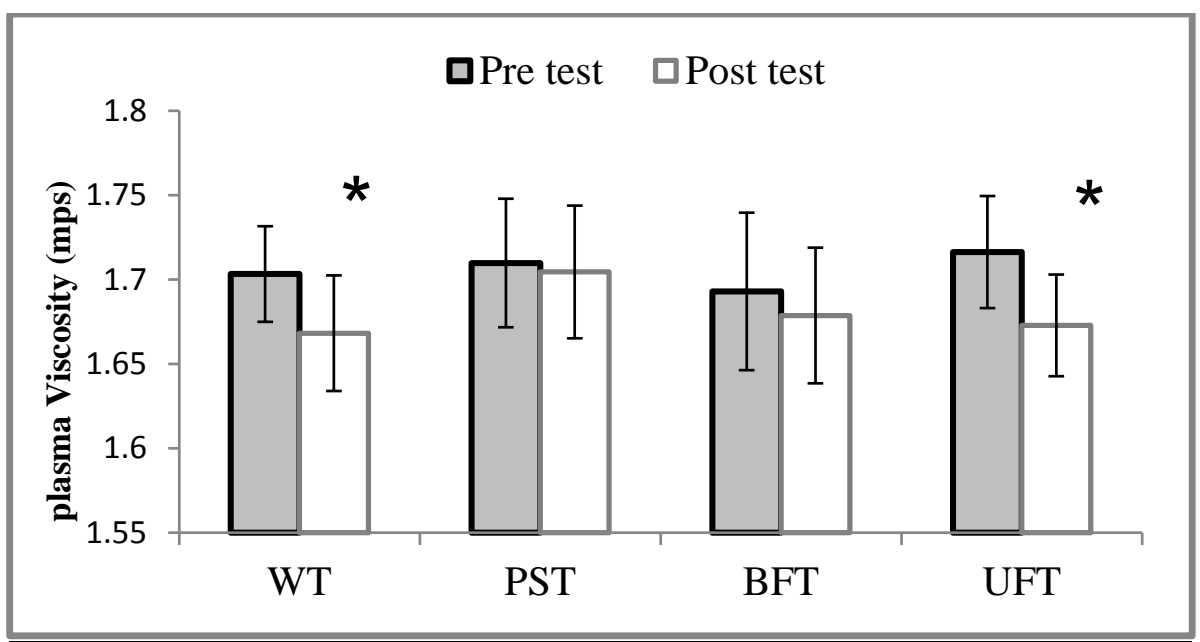

Fig 2. Viscosity data. *shows significant difference between pre-test and post-test data in the groups ( $\mathrm{p}<0.05$ ). WT, water-training; PST, petal sweat-training; BFT, bottom part of flower-training; UFT, upper part of flower-training. 


\section{DISCUSSION}

Sports activities cause changes in blood rheology corresponding with kind, duration, and intensity of the activity as well as an individual's physical fitness (23). Previous studies have indicated that changes in the blood hemorheology are induced by resistance exercises. Intensive resistance activity causes increases in the viscosity and fibrinogen of plasma (12).

In the present study, the effects of shortterm circuit exercise on the viscosity and fibrinogen of plasma with and without saffron supplementation were examined. Plasma fibrinogen decreased $10 \%$ after two weeks of short-term circuit resistance exercises. In agreement with this study, Ahmadizad et al. (12) found that intensive resistance activity increased fibrinogen levels in plasma, yet these levels returned to the baseline during a 30 -minute recovery period. They suggested that this mechanism probably occurs because of a decrease in blood plasma levels. Ghanbari Niaki et al. (7) found no changes in fibrinogen levels in response to 4 weeks of progressive aerobic exercises. Results of Ghanbari's study contradicts those of the present study. Results of the current study are in agreement with those of Kilic-Toprak et al. (24), who indicated a decrease in fibrinogen levels after three weeks of progressive resistance exercises; converse to the current study, however, they reported a return to baseline after twelve weeks (24). This contradiction was induced by the duration, intensity, and entity of resistance exercises used in the present study. Researchers found that circuit resistance exercises are more effective on increasing aerobic capacity and improving cardiorespiratory function than conservative resistance exercises $(25,26)$. Thus, considering the entity of circuit resistance exercises in this study, a possible mechanism of the decrease in fibrinogen level is the increase in plasma volume and improvement of the cardiovascular system.
Other possible mechanisms to reduce fibrinogen are an increase in nervous system activity and a change in the lipid profile (27, 28). Some studies have indicated an improvement in the lipid profile in response to resistance exercises $(29,30)$. A decrease in the lipid profile serves to decrease fibrinogen, because fibrinogen has a direct relationship with LDL and an inverse relationship with HDL (7). Increases in aerobic capacity and muscle mass induced by circuit resistance exercises (31) can improve lipid metabolism, and as a result, short-term, two-week circuit resistance exercises lead to reduced fibrinogen by improving lipid profiles and metabolism.

When a supplement from the upper part of the saffron flower was used during an exercise period, the effect of exercise was doubled and plasma fibrinogen was reduced $16 \%$, although there was no significant difference between this group and the others. The plasma fibrinogen in the PST group was reduced 5\%, which is a lower reduction compared with the UFT group. Through an examination of the materials of the petal sweat, bottom part, and upper part of the saffron flower, it was found that the upper part had more linoleic acid than its other parts. Moreover, safranal, the main material of saffron, exists only in the upper part. Researchers have indicated that saffron supplements improve lipid profiles (19).

Saffron also has antioxidant properties, and its supplement reduces blood coagulation by inhibiting lipid oxidation (17) and inhibiting platelet aggregation induced by ADP, epinephrine, and collagen (16). A possible reason for the decrease in blood coagulation is a reduction in coagulation factors like fibrinogen. In this study, an upper part of saffron supplement coupled with circuit resistance training reduced fibrinogen $16 \%$. A definite mechanism in this field has not yet been determined; more research is needed to achieve definite results. 
In general, blood circulation is reduced during sports activities, because the volume of plasma decreases and blood hematocrit increases (4). Blood hematocrit decreases after doing sports exercises because of the increase in plasma volume (32). Hematocrit is one of the main determinants of blood viscosity (4). Fibrinogen, the largest plasma protein and a main determinant of plasma and viscosity (7), was significantly reduced in all groups except BFT. In this study, resistance exercises reduced plasma viscosity by $2 \%$ in the WT group. In agreement with the present study, Kilic-Toprak et al. (24) indicated an $11 \%$ reduction in plasma viscosity after 3 weeks of progressive resistance exercises. This difference in reduction rates probably occurred because of the duration, intensity, and entity of the exercise periods. Plasma viscosity depends on plasma proteins, such as fibrinogen and globulin (33). Fibrinogen is one of the possible mechanisms for decreasing plasma viscosity. Increased levels of fibrinogen in plasma, increased platelet interaction with vessel walls, and intensification of homodynamic disorders lead to increased blood and plasma viscosity (4). It is well understood that increased platelet aggregation results in a rise in blood viscosity (34). In the present study, a $10 \%$ reduction in fibrinogen following circuit resistance exercises was associated with a $2 \%$ reduction in plasma viscosity. Researchers have indicated that high intensity resistance exercise led to increased platelet aggregation, but regular sports exercises led to increased plasma volume and decreased hematocrit in proportion to blood volume and, consequently, reduced plasma viscosity (35). Furthermore, the utilization of a supplement from the upper part of saffron in this study resulted in a $2.5 \%$ reduction in plasma viscosity during circuit resistance exercises. Although there was no significant differences between this group and the other groups, the rate of reduction was considerable in this group. This rate of reduction seems reasonable regarding the $16 \%$ decrease in fibrinogen. Examining the components of the upper part of saffron, it was understood that safranal, one of the main components of saffron, didn't exist in the bottom part or the petal sweat of saffron. Safranal has an antioxidant property which prevents lipid oxidation (36). The upper part of saffron also has more linolec acid than its petal sweat or bottom part, and it causes a reduction in vascular adhesive molecules and lipid deposits in vessel walls. Saffron supplements lead to increased blood circulation and decreased viscosity (20). Oleic acid causes a reduction in ADP and collagen-stimulating platelets and, consequently, results in a reduction of platelet aggregation (37). It seems, therefore, that an upper part of saffron supplement coupled with short-term circuit resistance training can cause a greater reduction in plasma fibrinogen levels and platelets aggregation and consequently, a slight reduction in plasma viscosity.

Studies have indicated that plasma viscosity has a significant relationship with physical fitness and heart function. In individuals who exercise, some parts of the reduction in viscosity is induced by a reduction in gamma globulin levels. Moreover, plasma viscosity and fibrinogen levels are lower in marathon runners than in individuals who did not exercise. That is because of the increase in plasma volume (4). This study examined subjects who did not exercise and had low physical fitness. Additionally, the duration of exercise and the time of saffron supplement use was short. Possibly, the short duration of exercise resulted in little adaptation in the cardiorespiratory system and, consequently, had little effect on plasma viscosity. It seems that more considerable changes can be observed with a longer duration of saffron supplement use and circuit training. Because there is no determined mechanism for saffron supplement with circuit training, more research is needed. 


\section{CONCLUSION}

The findings of the present study indicated that two weeks of short-term circuit resistance exercises caused a $10 \%$ reduction in plasma fibrinogen and a $2 \%$ reduction in plasma viscosity in proportion to pre-test data. The upper part of saffron supplement used with circuit resistance caused $16 \%$ and $2.5 \%$ post-test reductions, respectively, in fibrinogen and plasma viscosity. There was no significant difference between various parts of saffron with resistance training, but the upper part of saffron had more effects in comparison with its petal sweat and bottom part and doubled the effects of circuit training. Considering the results of this study, it can be concluded that saffron supplement use combined with two weeks of circuit resistance training can reduce cardiovascular risk factors (fibrinogen and plasma viscosity), although supplement with the upper part of saffron in combination with saffron caused a greater reduction in these risk factors.

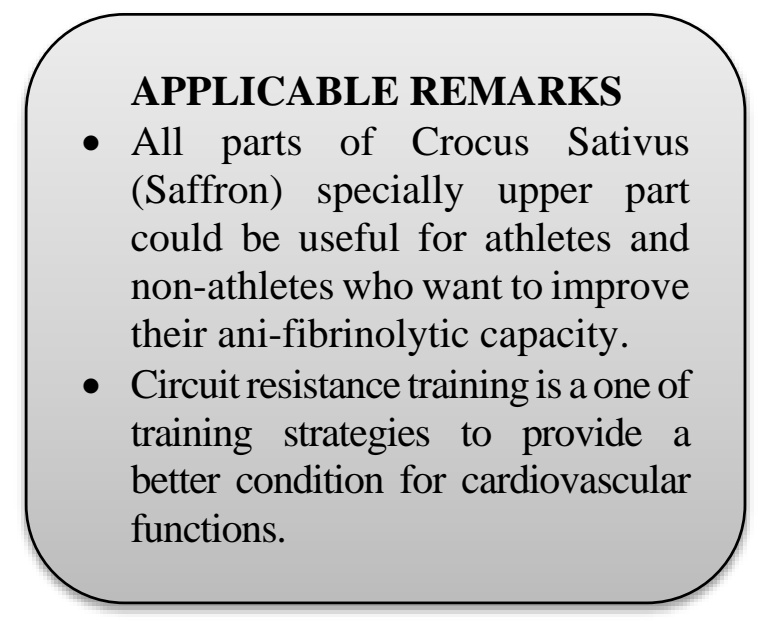

\section{REFFRENCES}

1. Organization WH. Cardiovascular diseases (CVDs) 2015. Fact sheet No317:[Available from: http://www.who.int/mediacentre/factsheets/fs317/en/.

2. Ajmani RS. Hypertension and hemorheology. Clinical hemorheology and microcirculation. 1997;17(6):397-420.

3. Lowe G, Rumley A, Norrie J, Ford I, Shepherd J, Cobbe S, et al. Blood rheology, cardiovascular risk factors, and cardiovascular disease: the West of Scotland Coronary Prevention Study. Thrombosis and haemostasis. 2000;84(4):553-8.

4. El-Sayed MS, Ali N, El-Sayed Ali Z. Haemorheology in exercise and training. Sports medicine (Auckland, NZ). 2005;35(8):649-70.

5. Varlet-Marie E, Gaudard A, Monnier JF, Micallef JP, Mercier J, Bressolle F, et al. Reduction of red blood cell disaggregability during submaximal exercise: relationship with fibrinogen levels. Clinical hemorheology and microcirculation. 2003;28(3):139-49.

6. el-Sayed MS, Davies B. A physical conditioning program does not alter fibrinogen concentration in young healthy subjects. Med Sci Sports Exerc. 1995;27(4):485-9.

7. Ghanbari-Niaki A, Behzad Khameslo M, Tayebi SM. Effect of Pyramidal Training on Plasma Lipid Profile and Fibrinogen, and Blood Viscosity of Untrained Young Men. Annals of Applied Sport Science. 2013;1(3):47-56.

8. Neuhaus D, Gaehtgens P. Haemorrheology and long term exercise. Sports medicine (Auckland, NZ). 1994;18(1):10-21.

9. Wood SC, Doyle MP, Appenzeller O. Effects of endurance training and long distance running on blood viscosity. Med Sci Sports Exerc. 1991;23(11):1265-9.

10. Banz WJ, Maher MA, Thompson WG, Bassett DR, Moore W, Ashraf M, et al. Effects of resistance versus aerobic training on coronary artery disease risk factors. Experimental biology and medicine (Maywood, NJ). 2003;228(4):434-40.

11. Ghanbari-Niaki A, Tayebi SM. Effects of a Light Circuit Resistance Exercise Session on Some Hematological Parameters of Male Collage Students. Annals of Applied Sport Science. 2013;1(1):6-11.

12. Ahmadizad S, El-Sayed MS. The acute effects of resistance exercise on the main determinants of blood rheology. Journal of sports sciences. 2005;23(3):243-9.

13. Ríos JL, Recio MC, Giner RM, Máñez S. An Update Review of Saffron and its Active Constituents. Phytotherapy Research. 1996;10(3):189-93.

14. Jessie SW, Krishnakantha TP. Inhibition of human platelet aggregation and membrane lipid peroxidation by food spice, saffron. Molecular and cellular biochemistry. 2005;278(1-2):59-63. 
15. Modaghegh MH, Shahabian M, Esmaeili HA, Rajbai O, Hosseinzadeh H. Safety evaluation of saffron (Crocus sativus) tablets in healthy volunteers. Phytomedicine : international journal of phytotherapy and phytopharmacology. 2008;15(12):1032-7.

16. Liakopoulou-Kyriakides M, Sinakos Z, Kyriakidis DA. A high molecular weight platelet aggregating factor in Crocus sativus. Plant Science. 1985;40(2):117-20.

17. Kianbakht S, Mozaffari K. Effects of Saffron and its Active Constituents, Crocin and Safranal, on Prevention of Indomethacin Induced Gastric Ulcers in Diabetic and Nondiabetic Rats. Journal of Medicinal Plants. 2009;1(29):30-8.

18. He SY, Qian ZY, Tang FT, Wen N, Xu GL, Sheng L. Effect of crocin on experimental atherosclerosis in quails and its mechanisms. Life sciences. 2005;77(8):907-21.

19. He SY, Qian ZY, Wen N, Tang FT, Xu GL, Zhou CH. Influence of Crocetin on experimental atherosclerosis in hyperlipidamic-diet quails. European journal of pharmacology. 2007;554(2-3):191-5.

20. Zheng S, Qian Z, Tang F, Sheng L. Suppression of vascular cell adhesion molecule-1 expression by crocetin contributes to attenuation of atherosclerosis in hypercholesterolemic rabbits. Biochemical pharmacology. 2005;70(8):1192-9.

21. Machado M, Koch AJ, Willardson JM, Pereira LS, Cardoso MI, Motta MK, et al. Effect of varying rest intervals between sets of assistance exercises on creatine kinase and lactate dehydrogenase responses. Journal of strength and conditioning research / National Strength \& Conditioning Association. 2011;25(5):1339-45.

22. Ghanbari A, Tayebi SM. The Effect of a Single Session of Eccentric Resistance Exercise on Some Parameters of White Blood Cells. Annals of Applied Sport Science. 2013;1(4):17-26.

23. Yalcin O, Erman A, Muratli S, Bor-Kucukatay M, Baskurt OK. Time course of hemorheological alterations after heavy anaerobic exercise in untrained human subjects. Journal of applied physiology (Bethesda, Md : 1985). 2003;94(3):997-1002.

24. Kilic-Toprak E, Ardic F, Erken G, Unver-Kocak F, Kucukatay V, Bor-Kucukatay M. Hemorheological responses to progressive resistance exercise training in healthy young males. Medical science monitor : international medical journal of experimental and clinical research. 2012;18(6):Cr351-60.

25. Alcaraz PE, Sanchez-Lorente J, Blazevich AJ. Physical performance and cardiovascular responses to an acute bout of heavy resistance circuit training versus traditional strength training. Journal of strength and conditioning research / National Strength \& Conditioning Association. 2008;22(3):667-71.

26. Pichon CE, Hunter GR, Morris M, Bond RL, Metz J. Blood Pressure and Heart Rate Response and Metabolic Cost of Circuit Versus Traditional Weight Training. The Journal of Strength \& Conditioning Research. 1996;10(3):153-6.

27. Smith J, Garbutt G, Lopes P, Pedoe D. Effects of prolonged strenuous exercise (marathon running) on biochemical and haematological markers used in the investigation of patients in the emergency department. British Journal of Sports Medicine. 2004;38(3):292-4.

28. Smith JE. Effects of strenuous exercise on haemostasis. British Journal of Sports Medicine. 2003;37(5):433-5.

29. Goldberg L, Elliot DL, Schutz RW, Kloster FE. Changes in lipid and lipoprotein levels after weight training. Jama. 1984;252(4):504-6.

30. Hurley BF, Hagberg JM, Goldberg AP, Seals DR, Ehsani AA, Brennan RE, et al. Resistive training can reduce coronary risk factors without altering VO2max or percent body fat. Med Sci Sports Exerc. 1988;20(2):150-4.

31. Kaikkonen H, Yrjama M, Siljander E, Byman P, Laukkanen R. The effect of heart rate controlled low resistance circuit weight training and endurance training on maximal aerobic power in sedentary adults. Scandinavian journal of medicine \& science in sports. 2000;10(4):211-5.

32. Ernst E, Daburger L, Saradeth T. The kinetics of blood rheology during and after prolonged standardized exercise. Clinical hemorheology and microcirculation. 1991;11(5):429-39.

33. Tsai AG, Cabrales P, Intaglietta M. Blood viscosity: A factor in tissue survival?*. Critical Care Medicine. 2005;33(7):1662-3.

34. Jayalalitha G, Shanthoshini Deviha V, Uthayakumar R. Fractal model for blood flow in cardiovascular system. Computers in Biology and Medicine. 2008;38(6):684-93.

35. Connes P, Simmonds MJ, Brun JF, Baskurt OK. Exercise hemorheology: classical data, recent findings and unresolved issues. Clinical hemorheology and microcirculation. 2013;53(1-2):187-99.

36. Hariri AT, Moallem SA, Mahmoudi M, Hosseinzadeh H. The effect of crocin and safranal, constituents of saffron, against subacute effect of diazinon on hematological and genotoxicity indices in rats. Phytomedicine : international journal of phytotherapy and phytopharmacology. 2011;18(6):499-504.

37. Thijssen MA, Hornstra G, Mensink RP. Stearic, oleic, and linoleic acids have comparable effects on markers of thrombotic tendency in healthy human subjects. The Journal of nutrition. 2005;135(12):2805-11. 
تازههاى علوم كاربردى ورزش

مقاله اصيل

دوره سوم، شماره دوم

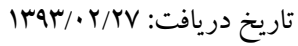

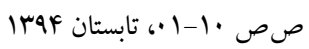

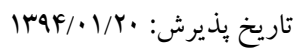

\section{تأثير تمرين مقاومتى دابرهاى همر اه با مكمل كرو كوس ساتيووس (زعفران) بر فيبرينوزن و ويسكوزيته بِلاسما}

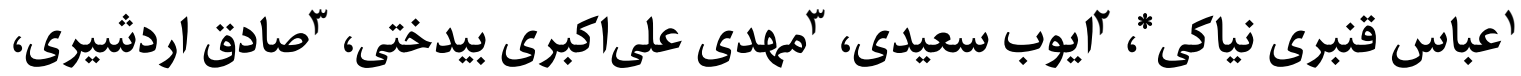

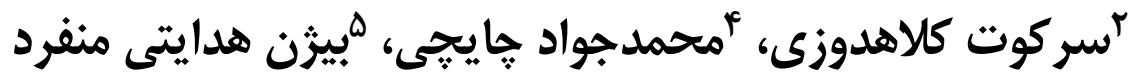

ا. استاد گروه بيوشيمى ورزشى، دانشكده تربيت بدنى و علوم ورزشى، دانشگاه مازندران، بابلسر، ايران.

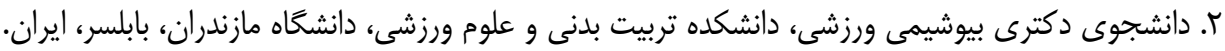

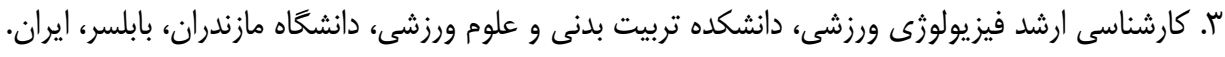

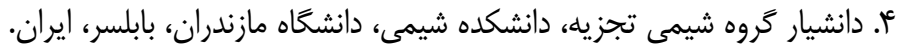

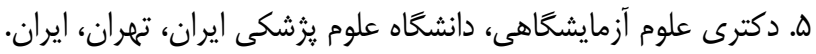

در مورد تأثير تركيب تمرين مقاومتى با مكمل دهى زعفران بر عوامل خطرزاى قلبى عروقى مطالعات محدودى انجام شده است. هدف از تحقيق

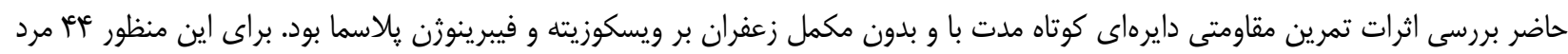

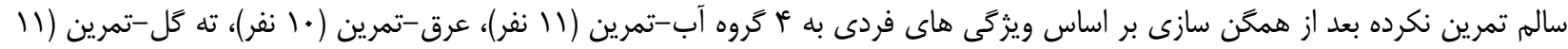

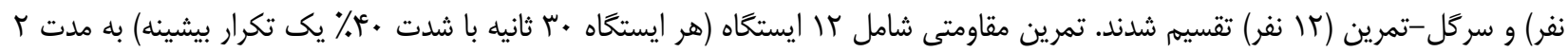

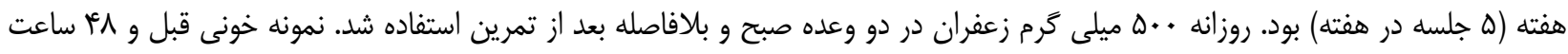

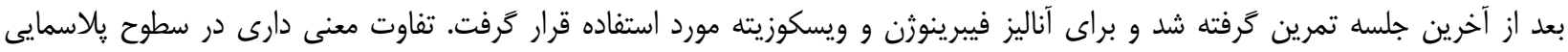

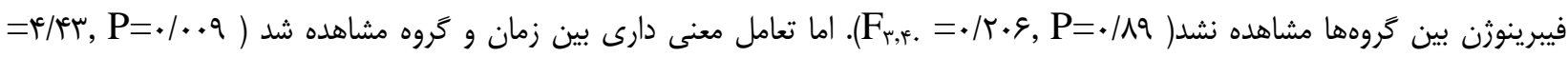

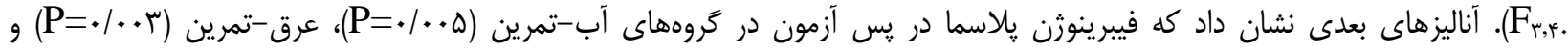

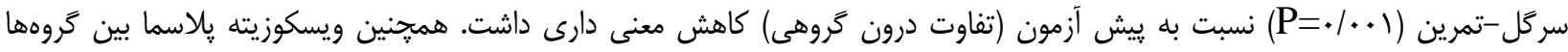

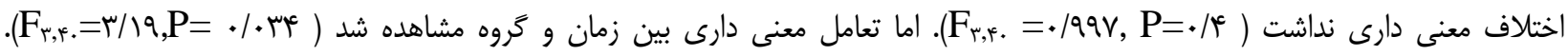

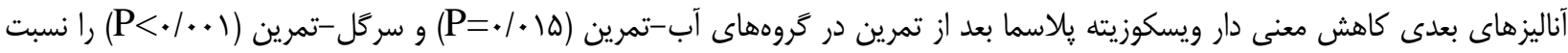

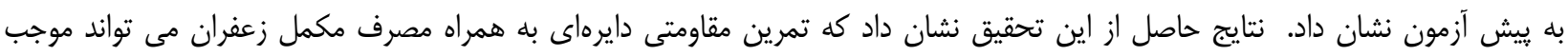

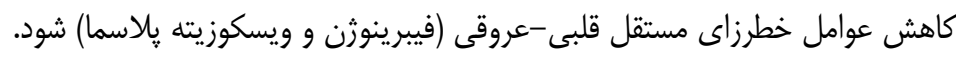

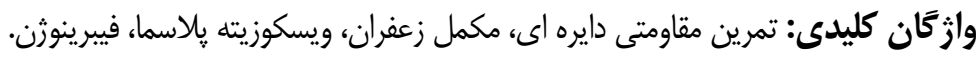

$$
\begin{aligned}
& \text { * - نوسنده مسئول: } \\
& \text { عباس قنبرى نياكى نئ } \\
& \text { وست الكترونيك: ghanbara@umz.ac.ir }
\end{aligned}
$$

